\title{
ENCERRANDO UM CICLO
}

Encerrar um ciclo significa também iniciar um novo. Estudamos, durante 0 ano de 1998, a possibilidade de inovar o projeto gráfico da RAE e utilizamos como benchmarking as mais prestigiosas revistas internacionais do nosso ramo. Quanto ao conteúdo, estamos recebendo inúmeras manifestações bastante elogiosas e, se não estivermos agradando plenamente, gostaríamos muito de saber. Afinal, discordar é próprio de pessoas inteligentes. Neste primeiro número do ano, em Organização, Recursos Humanos e Planejamento, Fernando Motta e Rafael Alcadipani enveredam pelo caminho da Antropologia buscando aprofundar nosso conhecimento sobre os mecanismos de controle social. De Clóvis Machado, renomado pesquisador em Administração, publicamos uma matéria sobre 0 processo de internacionalização do Banco Bamerindus e seus impactos nos esquemas interpretativos de seus dirigentes. $O$ artigo de Amélia Alves et al. é bastante inovador, pois apresenta os resultados de uma pesquisa que teve como objetivo construir um instrumento para a aferição da satisfação com o treinamento. Para Administração Mercadológica, reservamos o artigo sobre Marketing de Relacionamento, de autoria de Áurea Helena Puga Ribeiro. Anita Kon, em Economia de Empresas, analisa os serviços e a mudança de papel ocorrida no contexto do comércio internacional. Jacob Ancelevicz, professor da EAESP e sempre bem-vindo à $R A E$, juntamente com Carlos Khoury, aprofunda a temática dos sistemas de custeio. Alberto Albertin, dando seguimento a uma série de estudos sobre comércio eletrônico, nos apresenta suas análises sobre o setor bancário. Nossa matéria em língua inglesa, de Zeki Simsek, versa sobre pesquisa via mídia eletrônica. Neste número, trazemos também, em Administração Hospitalar, um artigo de autoria de Ernesto LimaGonçalves e Carlos Aché. A RAE continua com seu caderno RAE Light e suas resenhas. Novas seções deverão ser inauguradas ao longo de 1999.

A todos, desejo uma agradável leitura.

\section{Roberto Venosa}

Editor e Diretor 